\title{
Cushing disease
}

INSERM

\section{Source}

INSERM. (1999). Orphanet: an online rare disease and orphan drug data base. Cushing

disease. ORPHA:96253

Cushing disease (CD) is the most common cause of endogenous Cushing syndrome (CS; see this term) and is due to pituitary chronic over-secretion of ACTH by a pituitary corticotroph adenoma. 